\title{
Achalasia: Dilation, injection or surgery?
}

\author{
Alberto Peracchia MD FACS, Luigi Bonavina MD FACS
}

A Peracchia, L Bonavina. Achalasia: Dilation, injection or surgery? Can J Gastroenterol 2000;14(5):441-443. Achalasia results from irreversible alterations of the esophageal myenteric plexus. The target of treatment in this setting is to reduce lower esophageal sphincter resistance to passage of the bolus. Definitive treatment of the disease requires pneumatic dilation or Heller myotomy. Although no controlled studies comparing modern endoscopic and surgical techniques are available, laparoscopic surgery is emerging as the initial intervention of choice.

Key Words: Achalasia; Botulinum toxin; Fundoplication; Lower esophageal sphincter; Myotomy; Pneumatic dilation

\section{L'achalasie : dilatation, injection ou chirurgie ?}

RÉSUMÉ : L'achalasie résulte de modifications irréversibles du plexus myentérique œsophagien. Dans ce contexte, le traitement a pour but de réduire la résistance du sphincter œesophagien inférieur au passage du bol alimentaire. Le traitement définitif de la maladie nécessite une dilatation pneumatique ou une cardiomyotomie extramuqueuse de Heller. Bien qu'il n'existe aucune étude comparative portant sur les nouvelles techniques chirurgicales et endoscopiques, la chirurgie par laparoscopie émerge comme la première intervention d'élection.
Iinom diopathic achalasia is a motility disorder characterized by incomplete relaxation of the lower esophageal sphincter and impaired peristalsis of the esophageal body. Defective esophageal emptying leads to progressive dilation and tortuosity of the esophagus. Anatomic and physiological studies suggest a dysfunction of the myenteric plexus in these patients $(1,2)$, and an autoimmune pathogenesis has been hypothesized (3). The estimated annual incidence of the disease is $1 / 100,000$ persons.

Dysphagia and regurgitation are the two major symptoms of the disease. Nocturnal regurgitation can lead to aspiration pneumonia and pulmonary abscess. Inability to swallow leads to weight loss in more than half of the patients. The incidence of squamous cell carcinoma of the esophagus is greater in patients with long standing achalasia than in the control population $(4,5)$.

\section{DIAGNOSIS}

Diagnosis of achalasia requires the use of endoscopy, barium swallow study and esophageal manometry. Endoscopy must be performed in all patients to rule out other causes of dysphagia. Malignancy-induced secondary achalasia, often referred to as pseudoachalasia, should carefully be excluded.
Adenocarcinoma of the cardia is the most common tumour mimicking achalasia. Clinical features suggesting the possibility of a tumour are a short duration of dysphagia, a significant weight loss and an elderly patient. Because adenocarcinoma of the cardia may present as an infiltrating lesion with apparently normal mucosa, a computed tomographic scan and/or endoscopic ultrasonography should be used in selected cases $(6,7)$.

\section{PRINCIPLES OF THERAPY}

Current treatment modalities for achalasia are palliative and aim at improving esophageal emptying by reducing lower esophageal sphincter resistance to passage of the bolus. This effect can be achieved endoscopically by means of either pneumatic dilation (8-10) or botulinum toxin injection (11-13), and surgically by extramucosal myotomy (14-16). No firm consensus has been reached yet regarding the choice of the initial treatment. Retrospective studies have shown better results with myotomy performed by an experienced surgeon (17), and in the only prospective randomized trial myotomy gave better long term results compared with pneumatic dilation (18). Uncontrolled studies show that both procedures have equal success rates if skilled operators are

This mini-review was prepared from a presention made at the World Congress of Gastroenterology, September 6 to 11, 1998, Vienna, Austria Department of Surgery, University of Milan, Ospedale Maggiore Policlinico IRCCS, Milano, Italy

Correspondence and reprints: Dr Alberto Peracchia, Istituto di Chirurgia Generale e Oncologia Chirurgica, Ospedale Maggiore Policlinico,

Via F Sforza 35, 20122 Milano, Italy. Telephone +39-02-55035822, fax +39-02-55035810, e-mail bonavina@polic.cilea.it

Received for publication December 2, 1998. Accepted December 9, 1998 
available, and, therefore, the patient should be allowed to make his or her own decision (19). In the only controlled trial of botulinum toxin injection versus pneumatic dilation, both procedures were effective at one-year follow-up (13).

Two randomized, double-blind, placebo controlled trials have shown that chronic treatment with calcium-channel blockers, such as nifedipine or verapamil, does not significantly improve symptoms despite a marked decrease of lower esophageal sphincter pressure in up to $50 \%$ of the patients $(20,21)$. This form of therapy may be considered for short term management in individuals with relatively mild symptoms or as a temporary measure when more invasive procedures are contraindicated.

\section{DILATION}

Rigiflex balloon dilation of the esophagus is effective in more than two-thirds of patients. In up to $50 \%$ of the cases additional dilations are required to maintain symptomatic remission (10); the risk of perforation is estimated to be $1 \%$ to $6 \%$ in expert hands (22). Twenty-four hour esophageal $\mathrm{pH}$ monitoring shows gastroesophageal reflux in approximately one-third of the patients after dilation (23).

The effectiveness of dilation does not appear to depend on balloon size, dilation pressure, rapidity of inflation, duration of inflation, number of inflations per session or use of premedication. Patients who do not significantly respond to the first two dilations are unlikely to benefit from subsequent sessions, which may increase the risk of perforation (24).

\section{INJECTION}

The results of a double-blind trial of intrasphincteric injection of botulinum toxin compared with placebo showed that $66 \%$ of patients remained in remission six months after treatment, and the mean duration of a favourable response was 1.3 years (11). After a median follow-up of 2.4 years, only one-third of the patients were still in remission despite multiple injections. The response rate among patients older than 75 years was $75 \%$, while it was $27 \%$ among individuals younger than 50 years (12). The short term safety and effectiveness of the procedure have been confirmed in a French multicentre study (25).

Based on these early results it seems reasonable to consider the use of the toxin in the elderly patients and in those at risk for more invasive procedures (26). It remains to be clarified how long the effects of the injection will last and whether repeated injections will prove to be safe in the long term.

\section{SURGERY}

Extramucosal myotomy of the distal esophagus and cardia has been shown to achieve good symptomatic relief in about $95 \%$ of patients with idiopathic, previously untreated achalasia. When dissection of the cardia is minimal and an anterior antireflux procedure is added, gastroesophageal reflux is rare (16).

The advent of minimally invasive surgery in the management of benign esophageal disease, by lessening the surgical trauma to the chest and abdominal wall, has made surgery a more attractive option as a primary treatment (27-30). It has been shown that an extramucosal myotomy of the esophagus and cardia combined with a Dor fundoplication can be performed safely and effectively through laparoscopy, with clinical and functional results similar to that obtained with the open approach (31).

The operation is performed through a five-port access. Careful attention to technical details of the procedure is critical for a good surgical outcome. The incision of the lesser omentum is performed taking care to preserve the hepatic branch of the vagus nerve. Dissection is limited to the anterior surface of the esophagus and of the diaphragmatic crura to prevent postoperative reflux by preserving the anatomical relationships of the cardia.

The myotomy is started on the distal esophagus using an L-shaped hook until identification of the submucosal plane, and then continued with the Sugarbaker pericardiotomy scissors. Intraoperative endoscopy helps to identify the submucosal plan, to evaluate the length of the myotomy and to divide residual muscle fibres; additionally, it allows detection of possible mucosal tears that may be safely sutured laparoscopically. The incision is carried out for about $6 \mathrm{~cm}$ on the esophagus and $2 \mathrm{~cm}$ on the gastric side including the oblique fibres. An incomplete myotomy on the stomach represents the most common reason for a failed operation (32). The cardia is not mobilized except in patients with sigmoid esophagus; in such circumstances, it is preferable to reduce the redundancy in the abdomen and to close the crura posteriorly. The anterior fundic wall is then sutured to both the muscle edges of the myotomy and cranially to the crura. The addition of an anterior antireflux repair sutured to the muscle edges aids in preventing postoperative reflux and healing of the myotomy. After an uneventful Heller myotomy and Dor fundoplication, a gastrographin swallow study is performed on the first postoperative day. The patient is then allowed to drink and to have a soft diet, and is discharged the following day.

\section{EFFECT OF PREVIOUS TREATMENT ON SURGICAL OUTCOME}

Patients unsuccessfully treated by endoscopic dilation or intrasphinteric botulinum toxin injection are often referred for surgery. Transient tissue damage in the mucosa-submucosa layer has been documented by high resolution endoscopic ultrasonography (33), but it is unknown whether previous endoscopic treatment may cause histopathological changes leading to periesophageal inflammation, difficult identification of the circular or sling fibres, or difficult dissection of the submucosal plane. Recently, it has been found that patients who previously responded to botulinum toxin show a marked fibrotic reaction at the gastroesophageal junction leading to a higher rate of intraoperative mucosal tears and postoperative dysphagia $(34,35)$.

The increase in technical difficulties encountered at operation after injection therapy can be offset by adequate surgeon's experience; however, these preliminary observations suggest that injection of botulinum toxin should be reserved 
to patients who are not candidates for pneumatic dilation or laparoscopic Heller myotomy.

\section{CONCLUSIONS}

Pneumatic dilation and Heller myotomy are the two best established therapeutic options in achalasia. Which is the initial approach of choice is still matter of controversy. Although the efficacy of surgery is more predictable, in the absence of a large multicentre, controlled trial, it seems reasonable to state that when expertise in both procedures is available the patient should be clearly informed about the potential risks of each procedure and should make his or her own decision.

The impact of minimally invasive surgery in the treatment of achalasia has been almost as profound as in the treatment of cholelithiasis. The results of laparoscopic Heller myotomy combined with a partial fundoplication show equal efficacy and markedly reduced morbidity compared with the open surgical approach. It is for this reason that, in the near future, laparoscopy could emerge as the initial therapeutic approach of choice in achalasia.

\section{REFERENCES}

1. Goldblum JR, Whyte RI, Orringer MB, Appelman HD. Achalasia: a morphologic study of 42 resected specimens. Am J Surg Pathol 1994;18:327-37.

2. Mearin F, Mourelle M, Guarner F, et al. Patients with achalasia lack nitric oxide synthase in the gastro-oesophageal junction. Eur J Clin Invest 1993;23:724-8.

3. Verne GN, Sallustio JE, Eaker EY. Anti-myenteric neuronal antibodies in patients with achalasia: a prospective study. Dig Dis Sci 1997;42:307-13.

4. Peracchia A, Segalin A, Bardini R, Ruol A, Bonavina L, Baessato M. Esophageal carcinoma and achalasia: prevalence, incidence and results of treatment. Hepatogastroenterology 1991;38:514-6.

5. Sandler RS, Nyren O, Ekbom N, Eisen GM, Yuen J, Josefsson S. The risk of esophageal cancer in patients with achalasia. A population-based study. JAMA 1995;274:1359-62.

6. Kahrilas PJ, Kishk SM, Helm JF, Dodds WJ, Harig JM, Hogan WJ. A comparison of pseudoachalasia and achalasia. Am J Med 1987;82:439-46.

7. Spiess AE, Kahrilas PJ. Treating achalasia. From whalebone to laparoscope. JAMA 1998;280:638-42.

8. Vantrappen G, Hellemans J, Deloof W, Valembois P, Vandenbroucke J. Treatment of achalasia with pneumatic dilatations. Gut 1971;12:268-75.

9. Cusumano A, Bonavina L, Norberto L, et al. Early and long-term results of pneumatic dilatation in the treatment of oesophageal achalasia. Surg Endosc 1991;5:9-10.

10. Eckhardt V, Aignherr C, Bernhard G. Predictors of outcome in patients with achalasia treated by pneumatic dilation. Gastroenterology 1992;103:1723-38.

11. Pasricha PJ, Ravich WJ, Hendrix TR, Sostre S, Jones B, Kalloo AN. Botulinum toxin for the treatment of achalasia. N Engl J Med 1995;332:774-8

12. Pasricha PJ, Rai R, Ravich WJ, Hendrix TR, Kallooo AN. Botulinum toxin for achalasia: long-term outcome and predictors of response. Gastroenterology 1996;110:1410-5.

13. Annese V, Basciani M, Perri F, et al. Controlled trial of botulinum toxin injection versus placebo and pneumatic dilation in achalasia. Gastroenterology 1996;111:1418-24.

14. Ellis FH Jr, Crozier RE, Watkins E Jr. Operation for esophageal achalasia: results of esophagomyotomy without an antireflux operation. J Thorac Cardiovasc Surg 1984;88:344-51.

15. Csendes A, Braghetto I, Mascaro J, Henriquez A. Late subjective and objective evaluation of the results of esophagomyotomy in 100 patients with achalasia of the esophagus. Surgery 1988;104:469-75.

16. Bonavina L, Nosadini A, Bardini R, Baessato M, Peracchia A. Primary treatment of esophageal achalasia. Long-term results of myotomy and Dor fundoplication. Arch Surg 1992;127:222-6.

17. Okike N, Payne WS, Neufield DM, Bernatz PE, Pairolero PC, Sanderson DR. Esophagomyotomy versus forceful dilation for achalasia of the esophagus: results in 899 patients. Ann Thorac Surg 1979;28:119-25

18. Csendes A, Braghetto I, Henriquez A, Cortes C. Late results of a prospective randomised study comparing forceful dilatation and oesophagomyotomy in patients with achalasia. Gut 1989;30:299-304.

19. Abid S, Champion G, Richter JE, McElvein R, Slaughter RL, Koehler RE. Treatment of achalasia: the best of both worlds. Am J Gastroenterol 1994;89:979-85.

20. Traube M, Dubovik S, Lange R, McCallum R. The role of nifedipine therapy in achalasia: results of a randomized, double-blind, placebo-controlled study. Am J Gastroenterol 1989;84:1259-62.

21. Triadafilopoulos G, Aaronson M, Sackel S, Burakoff R. Medical treatment of esophageal achalasia. Double-blind crossover study with oral nifedipine, verapamil, and placebo. Dig Dis Sci 1991;36:260-7.

22. Schwartz H, Cahow C, Traube M. Outcome after perforation sustained during pneumatic dilatation for achalasia. Dig Dis Sci 1993;38:1409-13.

23. Patti M, Arcerito M, Tong J, et al. Importance of preoperative and postoperative $\mathrm{pH}$ monitoring in patients with esophageal achalasia. J Gastrointest Surg 1997;1:505-10.

24. Stuart R, Hennessy T. Primary disorders of oesophageal motility. Br J Surg 1989;76:1111-20.

25. Cuillière C, Ducritté P, Zerbib F, et al. Achalasia: outcome of patients treated with intrasphincteric injection of botulinum toxin. Gut 1997;41:87-92.

26. Castell DO, Katzka DA. Botulinum toxin for achalasia: to be or not to be? Gastroenterology 1996;110:1650-2.

27. Rosati R, Fumagalli U, Bonavina L, et al. Laparoscopic approach to esophageal achalasia. Am J Surg 1995;169:424-7.

28. Raiser F, Perdikis G, Hinder RA, et al. Heller myotomy via minimal-access surgery. An evaluation of antireflux procedures. Arch Surg 1996;131:593-7.

29. Hunter JG, Trus TL, Branum GD, Waring JP. Laparoscopic Heller myotomy and fundoplication for achalasia. Ann Surg 1997;225:655-64.

30. Pellegrini C. Impact and evolution of minimally invasive techniques in the treatment of achalasia. Surg Endosc 1997;11:1-2.

31. Ancona E, Anselmino M, Zaninotto G, et al. Esophageal achalasia: laparoscopic versus conventional open Heller-Dor operation. Am J Surg 1995;170:265-70.

32. Peracchia A, Bonavina L, Nosadini A, Baessato M, Bardini R. Management of recurrent symptoms after esophagomyotomy for achalasia. Dis Esophagus 1990;3:25-8.

33. Schiano TD, Fisher RS, Parkman HP, Cohen S, Dabezies M, Miller LS. Use of high-resolution endoscopic ultrasonography to assess esophageal wall damage after pneumatic dilation and botulinum toxin injection to treat achalasia. Gastrointest Endosc 1996;44:151-7.

34. Horgan S, Hudda K, Eubanks T, Pellegrini C. Does Botox injection make esophagomyotomy a more difficult operation? Surg Endosc 1998;12:553. (Abst)

35. Patti M, Feo C, Arcerito M, et al. The effects of previous treatment on the results of myotomy for achalasia. Digestive Disease Week. New Orleans, 1998. (Abst) 


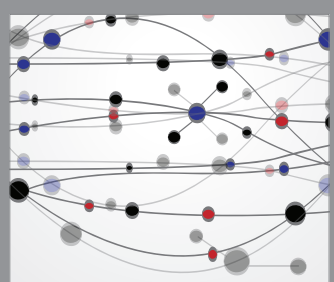

The Scientific World Journal
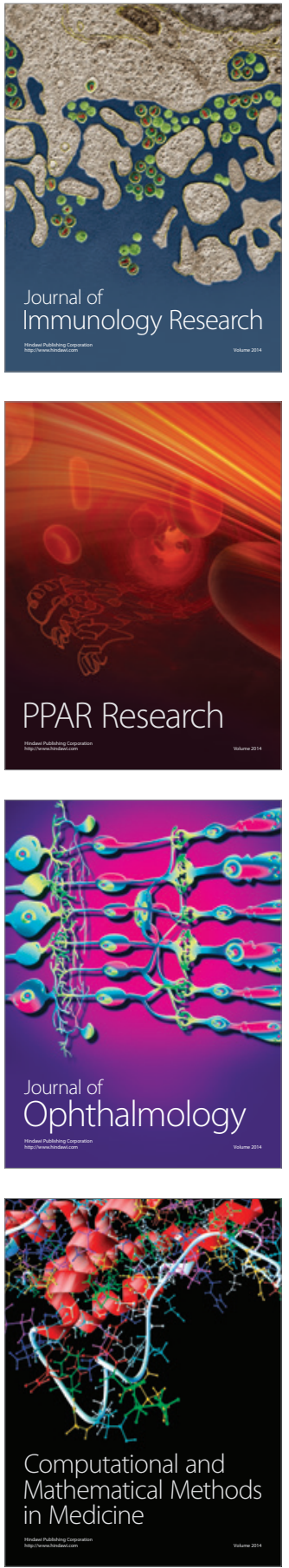

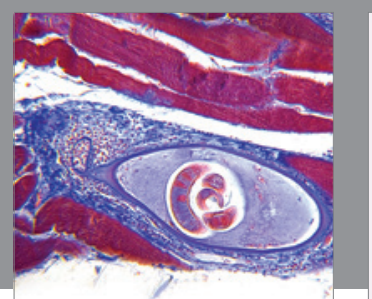

Gastroenterology Research and Practice

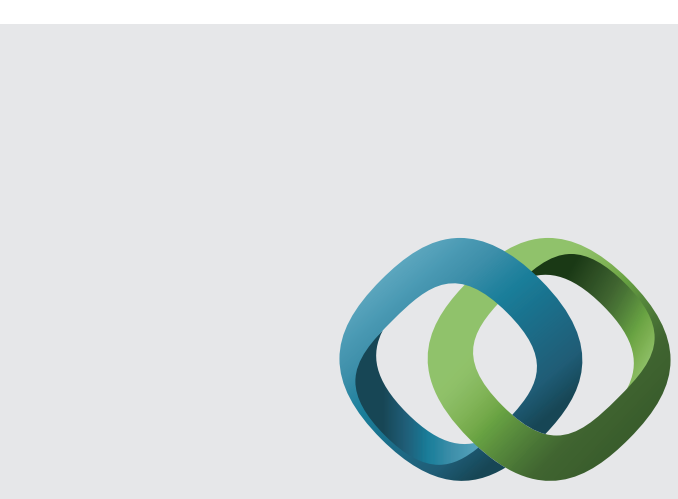

\section{Hindawi}

Submit your manuscripts at

http://www.hindawi.com
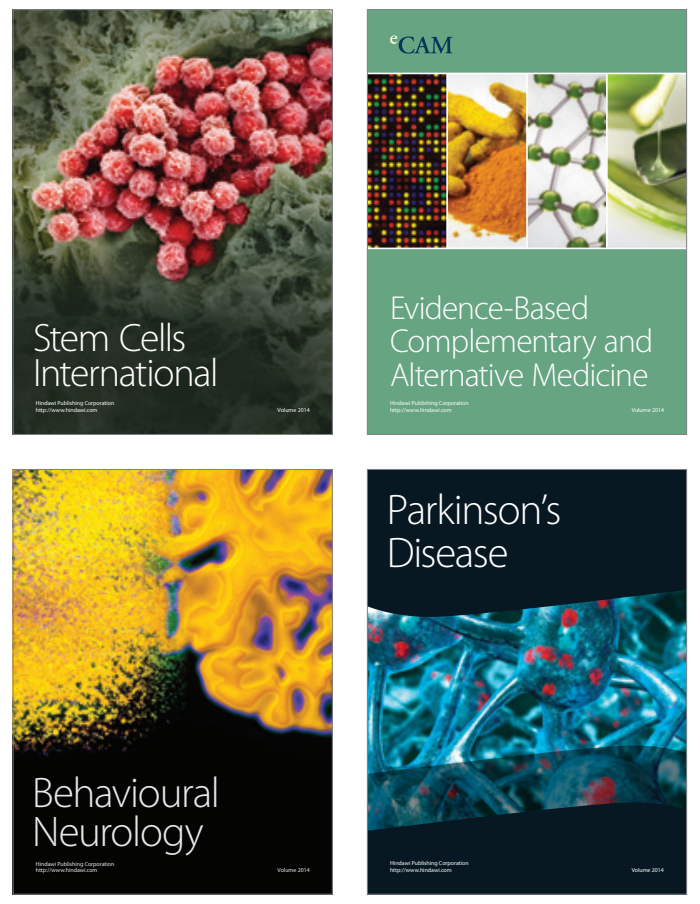
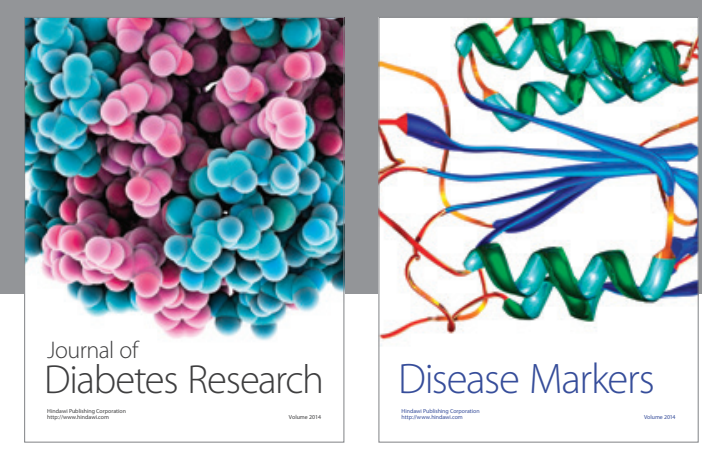

Disease Markers
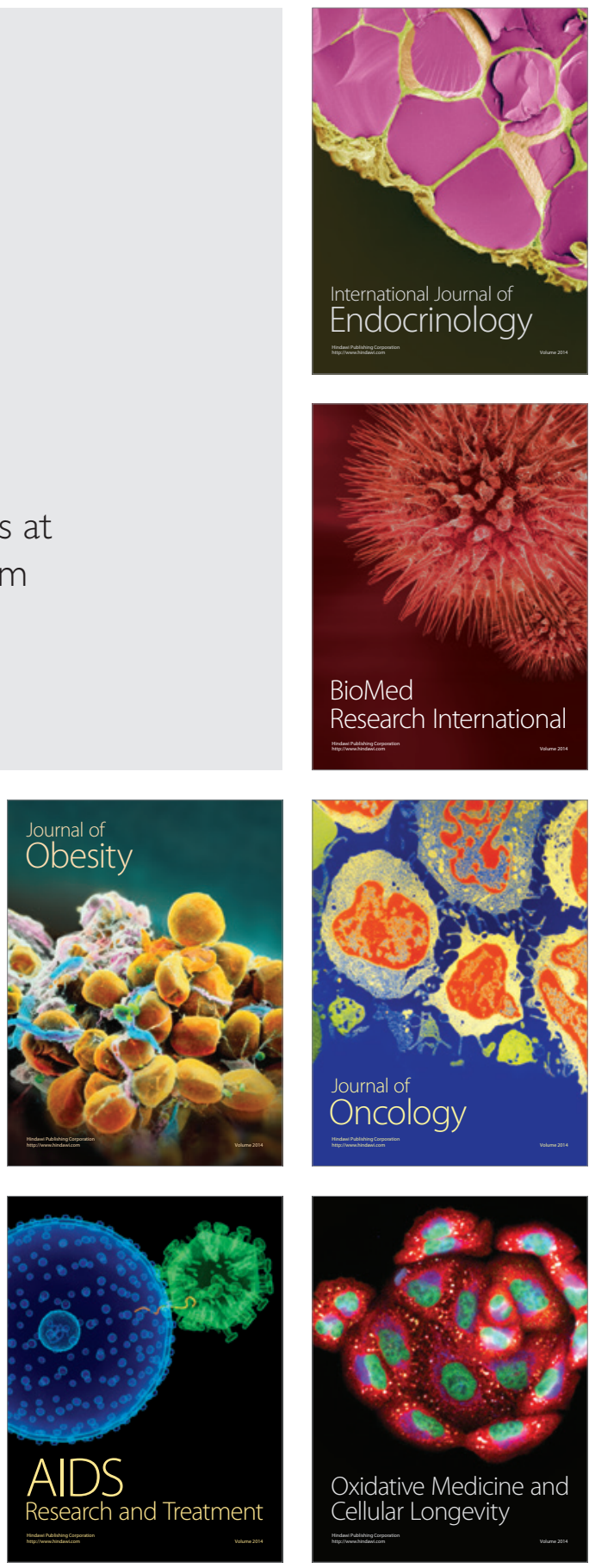